\title{
Nitrogen biogeochemistry in an unpolluted estuary: the importance of benthic denitrification
}

\author{
Sybil P. Seitzinger \\ Patrick Center for Environmental Research, Academy of Natural Sciences, Philadelphia, Pennsylvania 19103, USA
}

\begin{abstract}
Denitrification rates ( $\mathrm{N}_{2}$ production), and benthic ammonium, nitrate and oxygen fluxes were measured along a salinity gradient in Ochlockonee Bay (Florida, USA) over an annual cycle. Denitrification rates ranged from 0 to $210 \mu \mathrm{g}$-at $\mathrm{N} \mathrm{m}^{-2} \mathrm{~h}^{-1}$. Lowest rates of denitrification were measured in late winter and highest rates in late spring. A major portion of the organic nitrogen cycled through the sediments is denitrified; on an annual basis an average of $69 \%$ of the benthic nitrogen flux is $\mathrm{N}_{2}$ and $31 \%$ is ammonia, nitrite and nitrate. During summer the amount of nitrogen lost from the recycling pathway by denitrification is equivalent to about $40 \%$ of the nitrogen requirements of the phytoplankton. The major source of $\mathrm{NO}_{3}^{-}$or $\mathrm{NO}_{2}^{-}$for denitrification is from nitrification in the sediments, not diffusion of $\mathrm{NO}_{3}^{-}$or $\mathrm{NO}_{2}^{-}$from the overlying water. Denitrification is a major removal mechanism for nitrogen in Ochlockonee Bay, and removes, on an annual basis, an amount of nitrogen equivalent to $54 \%$ of the river input of dissolved inorganic nitrogen. $\mathrm{N}_{2} \mathrm{O}$ fluxes were small compared to $\mathrm{N}_{2}$ fluxes; $\mathrm{N}_{2} \mathrm{O} / \mathrm{N}_{2}$ ratios in March were less than 0.01 .
\end{abstract}

\section{INTRODUCTION}

It is well recognized that external ('new') inputs of nitrogen to most estuaries are not sufficient to supply the nitrogen needed to support annual primary production rates; rapid in situ recycling of nitrogen supplies a major portion of the nitrogen used by the algae (Harrison \& Hobbie 1974, reviews by Nixon 1981, Boynton et al. 1982). Both the water column (Harrison 1978, Caperon et al. 1979, Glibert 1982) and the sediments (Rowe et al. 1975, Nixon et al. 1976, Blackburn \& Henriksen 1983 and others) are important sites for nitrogen recycling in estuaries and other shallow coastal systems. However, during the mineralization of organic matter in sediments and in low oxic water, nitrogen can be lost from the recycling pathway as $\mathrm{N}_{2}$ if denitrification is occurring. The extent to which denitrification removes nitrogen as it is mineralized in a system influences the amount of nitrogen available for primary production.

Rates of denitrification have now been measured in sediments from numerous estuaries and other coastal marine systems (see Seitzinger [in press] for a review). However, only a few studies have evaluated the quantitative importance of denitrification relative to other nitrogen fluxes in coastal sediments (Billen 1978, Seitzinger et al. 1984, Kaspar et al. 1985). Denitrification in estuaries can also be important as a sink for anthropogenic and continentally derived $\mathrm{N}$ inputs to the oceans (Seitzinger et al. 1984). However, there is only one estuary where sufficient data have been reported to evaluate this (Seitzinger et al. 1984).

Most studies of estuarine nutrient dynamics, including essentially all estuarine denitrification studies, have been carried out in estuaries that receive significant amounts of pollutants, including nutrients from sewage sources. The purpose of the present study was to examine the role of the benthos as a sink for nitrogen in an estuary that is not dominated by anthropogenic nutrient inputs and pollutants. The magnitude of denitrification along a salinity gradient relative to benthic $\mathrm{NH}_{4}^{+}$and $\mathrm{NO}_{3}^{-}$fluxes is addressed as well as the importance of denitrification in decreasing the transport of continentally derived nitrogen to the oceans.

\section{METHODS}

Study site. Ochlockonee Bay is located on the 'panhandle' of Florida and empties into Appalachia Bay and the Gulf of Mexico (Fig. 1). The major freshwater flow into the bay is from the Ochlockonee River. The Apalachicola National Forest and St. Mark's National Wildlife refuge comprise the lower $105 \mathrm{~km}$ of the river's relatively undisturbed watershed. The upper 


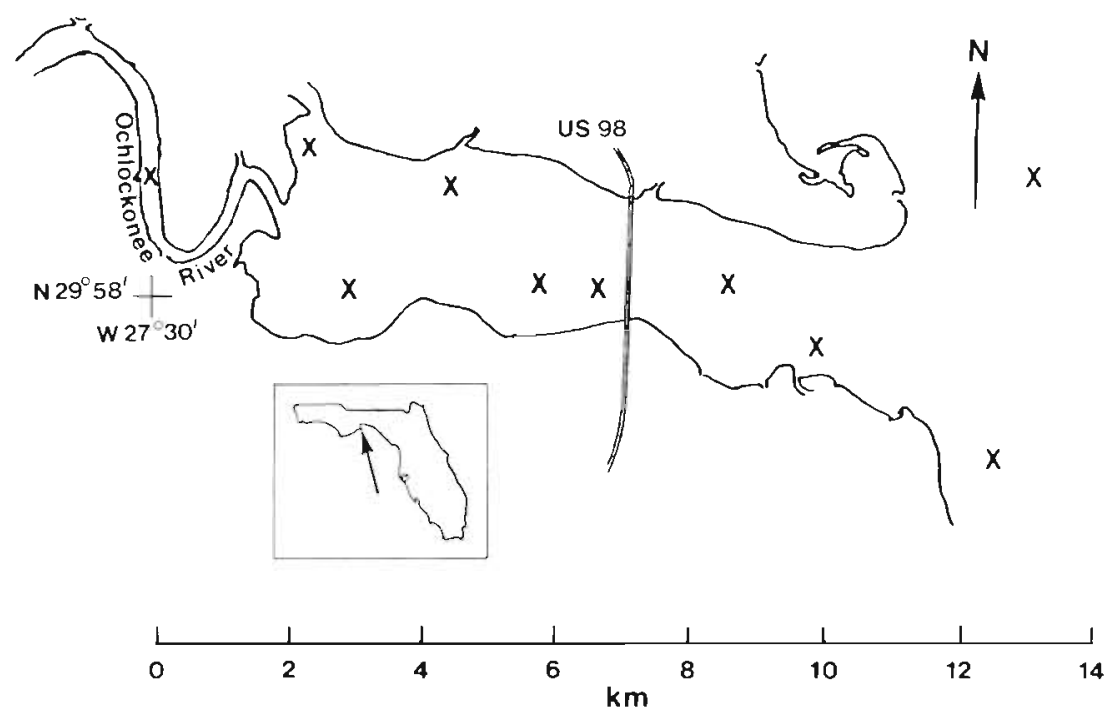

Fig. 1 Location of sediment sampling sites in Ochlockonee Bay (Florida, USA) for denitrification and sediment-water nutrient flux measurements. Distances $(\mathrm{km})$ of sites from river site are indicated

watershed is forested and sparsely populated. We know of no sewage treatment plants or industries that discharge into the river. The estuary is approximately $10 \mathrm{~km}$ long by $2.4 \mathrm{~km}$ wide. Average tidal range is $0.6 \mathrm{~m}$ and mean depth at low tide is $1 \mathrm{~m}$ (Kaul \& Froelich 1984). The depth of the lower $5 \mathrm{~km}$ of the Ochlockonee River ranges from 3 to $8 \mathrm{~m}$. The upper half of the bay is generally the shallowest, and much of the lower half of the bay ranges from 2 to $3 \mathrm{~m}$ deep at low tide. The water column is well-mixed with vertical salinity gradients of less than 1 ppt (m-depth $)^{-1}$. Phytoplankton production during summer is approximately 26 to $31 \mathrm{mg} \mathrm{C} \mathrm{m}{ }^{-2} \mathrm{~h}^{-1}$ (based on a $12 \mathrm{~h}$ day) as estimated from ${ }^{14} \mathrm{C}$ productivities (Myers \& Iverson 1981) and from modelling nutrient distributions in the bay (Kaul \& Froelich 1984). Nutrient concentrations are low throughout the bay, and generally decrease from the head of the bay, where the Ochlockonee River enters, to the mouth of the bay. Typical nutrient concentration ranges at the head and at the mouth of the bay, respectively, are: ammonia 1.8 to $2.5 \mu \mathrm{M}$ and $<0.5$ to $1.5 \mu \mathrm{M}_{\text {i }}$ nitrate 3 to $8 \mu \mathrm{M}$ and $<0.1$ to $1.8 \mu \mathrm{M}$; phosphate 0.5 to $1.6 \mu \mathrm{M}$ and 0.01 to $0.4 \mu \mathrm{M}$ (Kaul \& Froelich 1984, Seitzinger unpubl.).

Denitrification and sediment-water nutrient flux measurements. An initial study was carried out in June 1984 to assess the spatial heterogeneity of benthic nutrient fluxes in Ochlockonee Bay (Seitzinger unpubl.). The results of that study were used to choose a limited number of sites, representative of larger areas of the bay, for measurements of denitrification and benthic nutrient fluxes over an annual cycle. Sedimentwater fluxes of ammonium, nitrite plus nitrate, phosphate and oxygen were made at 30 locations throughout the bay (1 core per site) between 4 and 9 Jun 1984 . The spatial variability in the sediment-water nutrient and oxygen fluxes was low (Seitzinger unpubl.). Therefore, sites for seasonal measurements of denitrification and benthic nutrient fluxes were chosen that spanned the length of the estuary and included locations in the river, upper, mid and lower bay and outside the mouth of the bay (Fig. 1).

Sediment cores for denitrification and benthic nutrient flux measurements were collected on $21 \mathrm{Apr}$ 1984, 4 to 5 Jun 1984, 17 Nov 1984, and 19 Mar 1985 from 5 areas in the bay. The sediment cores $(6.7 \mathrm{~cm}$ diameter, ca $15 \mathrm{~cm}$ deep) were collected by SCUBAequipped divers using plastic coring tubes. Care was taken during coring to avoid disturbance of the sediment surface and loss of flocculent material. At the time of sediment collection water was collected from each location in acid-washed carboys. The cores were kept dark and maintained at ambient bay water temperature during transport to the laboratory. Denitrification rates ( $\mathrm{N}_{2}$ production) and benthic nutrient fluxes were measured according to techniques previously described in detail in Seitzinger et al. (1980) and Seitzinger \& Nixon (1985); only the general outline and recent modifications of the method are described here.

The sediment cores $7 \mathrm{~cm}$ deep; 1 core per sampling location) were transferred to gas-tight glass incubation chambers which had been filled with helium for a number of days prior to the beginning of the experiment. The cores were incubated in the dark with unfiltered bay water $(\sim 300 \mathrm{ml})$ which was stirred continuously with a floating magnetic stirring bar to facilitate the equilibration of dissolved gases with the overlying gas phase $(\sim 70 \mathrm{ml})$. Water over the cores was changed at approximately 24 to $48 \mathrm{~h}$ intervals with freshly prepared low $-\mathrm{N}_{2}$ bay water obtained by flushing water from the site of sediment collection. with a gas mixture of $21 \% \mathrm{O}_{2}$ and the balance He. The incubation temper- 
ature was the same as the ambient bay water temperature at the time of sediment collection. The oxygen concentration in the water over the sediments throughout the experiment was always above $70 \%$ saturation relative to atmospheric $\mathrm{O}_{2}$.

Duplicate samples $(100 \mu \mathrm{l})$ of the gas phase were taken for $\mathrm{N}_{2}$ and $\mathrm{O}_{2}$ analysis from each chamber approximately 6,24 , and occasionally $48 \mathrm{~h}$ after the water was changed. Net $\mathrm{N}_{2}$ and $\mathrm{O}_{2}$ fluxes across the sediment-water interface were calculated knowing the changes in concentration between sequential samples during an incubation and the volume of the gas phase in each chamber. Gas samples were injected directly into a gas chromatograph (Shimadzu, Model GC-8A) equipped with a thermal conductivity detector $(2 \mathrm{~m} \times$ $0.318 \mathrm{~cm}$ o.d. stainless steel columns packed with $45 / 60$ mesh Molecular Sieve $5 \mathrm{~A}, \mathrm{He}$ carriér gas flow rate $25 \mathrm{~cm}^{-3} \mathrm{~min}^{-1}$ ).

Previous experiments (Seitzinger 1982) showed that the $\mathrm{N}_{2}$ initially dissolved in the pore waters became equilibrated with the low $-\mathrm{N}_{2}$ overlying water in about $10 \mathrm{~d}$. Ten $\mathrm{d}$ also appears to be sufficient in the present experiments because $N_{2}$ fluxes were below the level of detection ( $<25 \mu \mathrm{g}$-at $\left.\mathrm{N} \mathrm{m}^{-2} \mathrm{~h}^{-1}\right)$ after $10 \mathrm{~d}$ from sediments with no measurable denitrification (see 'Results'), and the rate of $\mathrm{N}_{2}$ flux did not decrease after $10 \mathrm{~d}$ from cores with measurable denitrification rates. Therefore, measurements made after $10 \mathrm{~d}$ of incubation with low $-\mathrm{N}_{2}$ water were used for calculations of denitrification rates. Two to 4 separate denitrification rate $\left(\mathrm{N}_{2}\right.$ flux $)$ measurements were made on each core.

Sediment-water nutrient fluxes were measured from the same cores used for denitrification measurements. Initial water samples for sediment-water nutrient fluxes were taken from a chamber after the water was changed over a core but before the chamber was closed for $\mathrm{N}_{2}$ flux measurements. Final samples were taken approximately 24 or $48 \mathrm{~h}$ later after the final gas sample was collected. A portion of each sample was filtered through pre-rinsed glass fiber filters (Whatman 934$\mathrm{AH}$ ) and frozen for later analysis of nitrite plus nitrate (Technicon Industrial Systems 1977). The unfiltered portion of the sample was analyzed immediately for ammonium (Solorzano 1969). Ammonium samples were not filtered because comparisons of filtered and unfiltered samples consistently indicated a small contamination due to filtering.

Changes in nutrient concentrations attributable to water column processes were measured by incubating water from each station without sediment. These controls were treated and sampled using the same procedures as were used for sampling the water over the cores. The sediment-water flux of nutrients was calculated based on the volume of water over the cores and the change in nutrient concentration between initial and final water samples from the cores after correcting for any changes noted in the controls.

During the March experiment time series samples $(1.5 \mathrm{ml})$ of the gas phase were taken for $\mathrm{N}_{2} \mathrm{O}$ analysis from each chamber. Nitrous oxide fluxes were measured on days when $\mathrm{N}_{2}$ fluxes were not. Samples were injected directly into a gas chromatograph (Shimadzu, Model GC-8A) equipped with a ${ }^{63} \mathrm{Ni}$ electron capture detector $\left(340^{\circ} \mathrm{C}\right.$ ) and a $4.3 \mathrm{~m} \times 0.318 \mathrm{~cm}$ (o.d.) stainless steel column packed with Poropak Q, 80/100 mesh $\left(\mathrm{CH}_{4} / \mathrm{Ar}\right.$ carrier gas flow $\left.20 \mathrm{~cm}^{-3} \mathrm{~min}^{-1}\right)$. The total amount of nitrous oxide in the water and gas phases of the chambers was calculated using the $\mathrm{N}_{2} \mathrm{O}$ solubility equation of Weiss \& Price (1980) for the appropriate temperature and salinity.

Controls. To demonstrate the gas tightness of the incubation chambers, the ability to sample from the chambers without contamination, and the biological (denitrification) source of the $\mathrm{N}_{2}$ produced, the following measurements were made: (1) The $N_{2}$ concentration was measured over time in empty, helium-filled chambers. (2) The $\mathrm{N}_{2}$ flux from the sediments was measured with anoxic conditions in the water and gas phases at the end of the November 1984 denitrification measurements.

Pore water ammonium concentrations were measured in an upper bay $(2.5 \mathrm{~km}$ site) and a mid bay (5.4 km site) core in June 1985. Cores were sectioned at $1 \mathrm{~cm}$ intervals in a glove bag continuously flushed with $\mathrm{N}_{2}$. Pore waters were extracted in the glove bag by filtering the wet sediment through pre-rinsed, dried, glass fiber filters. The samples were analyzed immediately for ammonium after dilution with deionized distilled water (Solorzano 1969).

Dissolved inorganic nitrogen inputs to the bay from the Ochlockonee River were estimated from the ammonium and nitrite plus nitrate concentrations measured in the river $(<1 \%$ salinity). Water samples were collected the day after the sediment cores were collected. Samples for nitrite plus nitrate (Technicon Industrial Systems 1977) were filtered through prerinsed glass fiber filters and frozen for later analysis. Unfiltered ammonium samples were analyzed immediately (Solorzano 1969).

\section{RESULTS}

Measurable rates of denitrification $(>25 \mu \mathrm{g}$-at $\mathrm{N}$ $\mathrm{m}^{-2} \mathrm{~h}^{-1}$ ) were found in Ochlockonee Bay at all seasons (Table 1). Denitrification rates were lowest in late winter (March), ranging from 0 to $65 \mu \mathrm{g}$-at $\mathrm{N} \mathrm{m}^{-2} \mathrm{~h}^{-1}$, and highest in late spring (April), ranging from 100 to $210 \mu \mathrm{g}$-at $\mathrm{N} \mathrm{m}^{-2} \mathrm{~h}^{-1}$. No measurable denitrification was 
Table 1. Denitrification rates $\left(\mathrm{N}_{2}\right.$ production), oxygen consumption, and net flux of $\mathrm{NO}_{3}^{-}+\mathrm{NO}_{2}^{-}, \mathrm{NH}_{4}^{+}, \mathrm{N}_{2} \mathrm{O}$ from intact sediment cores collected from Ochlockonee Bay, Florida, USA (see Fig. 1). Rates are mean rate for a core; units: $\mu \mathrm{g}-\mathrm{at}(\mathrm{N}$ or $\mathrm{O}) \mathrm{m}^{-2} \mathrm{~h}^{-1}$

\begin{tabular}{|c|c|c|c|c|c|c|c|c|c|c|}
\hline Month & $\begin{array}{c}\text { Distance } \\
(\mathrm{km})\end{array}$ & $\begin{array}{l}\text { Approx. } \\
\text { depth (m) }\end{array}$ & $\begin{array}{c}\text { Salinity } \\
\left({ }^{\circ} \%\right)\end{array}$ & $\begin{array}{l}\text { Temp. } \\
\left({ }^{\circ} \mathrm{C}\right)\end{array}$ & $\mathrm{N}_{2}$ & $\mathrm{NO}_{2}+\mathrm{NO}_{3}$ & $\mathrm{NH}_{4}$ & $\begin{array}{c}\mathrm{O}_{2} \\
\text { uptake }\end{array}$ & $\mathrm{N}_{2} \mathrm{O}$ & Visual sediment characteristics ${ }^{\circ}$ \\
\hline \multirow[t]{5}{*}{ Apr 84} & 0.0 & 2.0 & 0 & \multirow[t]{5}{*}{21} & 155 & 4 & 2 & 1625 & & Mud, no animals visible \\
\hline & 2.4 & 1.3 & 0 & & 130 & 7 & 16 & 1345 & & Medium sand, no animals visible \\
\hline & 4.4 & 1.0 & 0 & & 100 & 4 & 4 & 1250 & & Find sand with mud, NT \\
\hline & 8.7 & 2.0 & 2 & & 210 & 20 & -61 & 1840 & & Mud, very soft, NT \\
\hline & 12.1 & 3.3 & 6 & & 155 & 0 & 105 & 1250 & & Medium sand with mud, MT \\
\hline \multirow[t]{5}{*}{ Jun 84} & 0.0 & 2.0 & 0 & \multirow[t]{5}{*}{25} & 75 & 14 & 46 & 510 & & Mud, no animals visible \\
\hline & 2.9 & 1.5 & 0 & & 35 & 2 & 63 & 1230 & & Mud, soft, FT \\
\hline & 5.8 & 2.0 & 1 & & 105 & 28 & 83 & 1235 & & Mud, MT \\
\hline & 9.8 & 1.5 & 14 & & 95 & 14 & 78 & 1360 & & Mud, no animals visible \\
\hline & 12.1 & 3.3 & 27 & & 55 & 18 & 15 & 1120 & & Fine sand w/mud, no animals visible \\
\hline \multirow[t]{5}{*}{ Nov 84} & 2.4 & 1.5 & 8 & \multirow[t]{5}{*}{16} & 110 & 14 & -6 & 925 & & Mud, soft, MT \\
\hline & 2.9 & 1.5 & 14 & & 95 & 17 & -6 & 915 & & Mud, soft, FT \\
\hline & 6.6 & 2.0 & 14 & & 130 & 49 & -12 & 1045 & & Mud, very soft, FT \\
\hline & 8.7 & 2.0 & 18 & & 80 & 20 & -2 & 615 & & Mud, soft, no animals visible \\
\hline & 11.8 & 1.3 & 2 & & 0 & 0 & 5 & 400 & & Fine sand, no animals visible \\
\hline \multirow[t]{5}{*}{ Mar 85} & 0.0 & 1.0 & 0 & \multirow[t]{5}{*}{17} & 30 & 10 & 6 & 510 & 0.04 & Top $1 \mathrm{~mm}$ mud, below fine sand $\mathrm{w} / \mathrm{mud}$ \\
\hline & 2.9 & 1.5 & 4 & & 55 & 29 & 8 & 1590 & 0.05 & Mud, soft, MT \\
\hline & 6.6 & 2.0 & 15 & & 65 & 29 & 2 & 990 & 0.02 & Mud, 1 oyster shell \\
\hline & 8.7 & 2.0 & 15 & & $\mathrm{~nm}$ & 18 & 2 & 1565 & 0.04 & Mud, soft, MT \\
\hline & 12.1 & 3.3 & 22 & & 0 & 22 & 26 & 2020 & 0.03 & Fine sand, brittle stars \\
\hline
\end{tabular}

found in November or March in sediments collected outside the mouth of the bay. Rates of denitrification measured in June were similar to those measured in late fall. Within a season, there was no obvious relationship between denitrification rate and location within the bay, salinity, sediment characteristics or abundance of infauna (Table 1).

Sediment-water ammonium fluxes were generally low in April, November, and March (Table 1). At 4 locations in November and 1 in April there was a net flux of ammonium into the sediments. Ammonium fluxes were higher in June. There was no obvious pattern of ammonium fluxes with station location, temperature or salinity. There was a net flux of nitrite plus nitrate out of the sediments at all locations during all sampling times, except from sediments collected outside the mouth of the bay. In April and November sediments from that location exhibited no net flux of nitrite plus nitrate into or out of the sediments.

Pore water $\mathrm{NH}_{4}^{+}$concentrations increased with depth in cores collected from an upper and a mid-bay location in June 1985. At the upper bay location, ammonium concentrations increased from $90 \mu \mathrm{M}$ in the top 0 to $1 \mathrm{~cm}$ to $320 \mu \mathrm{M}$ in the 4 to $5 \mathrm{~cm}$ section. At the mid-bay location, ammonium concentrations increased from $72 \mu \mathrm{M}$ in the top 0 to $1 \mathrm{~cm}$ to $190 \mu \mathrm{M}$ in the 4 to $5 \mathrm{~cm}$ section

Nitrous oxide fluxes were small relative to $\mathrm{N}_{2}$ fluxes and ranged from 0.02 to $0.05 \mu \mathrm{g}$-at $\mathrm{N} \mathrm{m}^{-2} \mathrm{~h}^{-1}$ in March (Table 1).

No $\mathrm{N}_{2}$ influx into empty, helium-flushed incubation chambers could be detected (Table 2). At the end of the November denitrification measurements, the chambers were allowed to go anoxic and $\mathrm{N}_{2}$ flux measurements

Table 2. $\mathrm{N}_{2}$ production rates in empty helium-flushed chambers and in chambers with sediment cores during the November denitrification experiment with aerobic overlying water and with anaerobic overlying water. Rates reported as average flux ( $\mu \mathrm{g}$-at $\left.\mathrm{N} \mathrm{m}^{-2} \mathrm{~h}^{-1}\right) \pm \mathrm{SD}$

\begin{tabular}{|lcc|}
\hline Chamber \#/Station & $N_{2}$ flux & No. measurements \\
\hline Empty chambers & & \\
$\# 1$ & 0 & 2 \\
$\# 2$ & 0 & 2 \\
Aerobic with sediments & \\
$1.9 \mathrm{~km}$ & $108 \pm 59$ & 4 \\
$2.5 \mathrm{~km}$ & $95 \pm 35$ & 4 \\
$5.4 \mathrm{~km}$ & $131 \pm 59$ & 4 \\
$7.2 \mathrm{~km}$ & $79 \pm 44$ & 3 \\
Anaerobic with sediments & \\
$1.9 \mathrm{~km}$ & $-6 \pm 26^{\circ}$ & 6 \\
$2.5 \mathrm{~km}$ & $-1 \pm 31^{\circ}$ & 5 \\
$5.4 \mathrm{~km}$ & $3 \pm 17^{\circ}$ & 3 \\
$7.2 \mathrm{~km}$ & $8 \pm 12^{\circ}$ & 7 \\
& & \\
Flux not different from zero $(\alpha=0.05)$ & \\
\hline
\end{tabular}


were continued. As expected, $\mathrm{N}_{2}$ fluxes under anoxic conditions were not significantly different from zero $(\alpha<0,05)$. Without oxygen no further nitrification could occur and thus no denitrification occurred

Nitrogen inputs to Ochlockonee Bay from the Ochlockonee River during 1984-85 were estimated from measured $\mathrm{NH}_{4}^{+}+\mathrm{NO}_{3}^{-}+\mathrm{NO}_{2}^{-}$concentrations in the river and by making certain adjustments to Kaul \& Froelich's (1984) estimate of nitrogen inputs to the bay during 1980-81. Their estimate of 0.2175 moles $\mathrm{N} \mathrm{s}^{-1}$ was made by multiplying the Ochlockonee River flow during $1980-81$ by the nitrite plus nitrate concentration measured monthly in the river. I have made adjustments to their estimate for (1) the difference in river flow in 1980-81, a severe drought year, to that in 1984-85, a more normal flow year, and (2) the ammonium supplied to the bay from the river.

The river flow into Ochlockonee Bay varies substantially from year to year; the 23 yr average flow of the Ochlockonee River at the Jackson Bluff dam from 1960 through 1982 was $53 \pm 24 \mathrm{~m}^{3} \mathrm{~s}^{-1}$ (U.S. Geological Survey unpubl.). The average flow during the period of Kaul \& Froelich's study (1980-1981) was $20 \mathrm{~m}^{3} \mathrm{~s}^{-1}$ while during 1984-1985 it was approximately 3 times larger, $62 \mathrm{~m}^{3} \mathrm{~s}^{-1}$ (U.S. Geological Survey unpubl.) and similar to the $23 \mathrm{yr}$ average flow. The Jackson Bluff dam is about $105 \mathrm{~km}$ upstream from the mouth of the Ochlockonee River. The river flow at the dam is taken to be representative of the discharge into the bay because there are no major tributaries or distributaries between the dam and the mouth of the river.

Ammonium concentrations measured in the Ochlockonee River during 1984-85 ranged from 1.8 to $2.5 \mu \mathrm{M}$ and averaged $38 \%$ of the nitrite plus nitrate concentrations. These ammonium concentrations are similar to those measured in unpolluted tropical rivers reviewed by Meybeck (1982) which range from 0.5 to $2.9 \mu \mathrm{M}$. The river concentrations of nitrite plus nitrate ( 3 to $8 \mu \mathrm{M}$ ) measured during the present study were essentially the same as those measured during similar months in 1980-1981 by Kaul \& Froelich (1984), despite the difference in river flow rates. Since the frequency of river nutrient concentration measurements made in the present study is low compared to the monthly measurements of Kaul \& Froelich, adjustments to account for the ammonium inputs to Ochlockonee Bay were made by multiplying Kaul \& Froelich's (1984) nitrite plus nitrate input rate by 1.38 . The combined adjustments made to Kaul \& Froelich's (1984) 1980-81 estimate of riverine $N$ inputs to calculate the riverine inputs of inorganic $N$ to Ochlockonee Bay in 1984-85 are: $\left(0.2175\right.$ moles $\left.\mathrm{N} \mathrm{s}^{-1}\right) \times 1.38$ (ammonium) $\times 3$ (flow) $=$ 0.90 moles $\mathrm{N} \mathrm{s}^{-1}$ or $135 \mu \mathrm{g}$-at $\mathrm{N} \mathrm{m}^{-2} \mathrm{~h}^{-1}$ (area of bay $24 \times 10^{6} \mathrm{~m}^{2}$; determined from planimetry of U.S. Geological Survey maps 00624 and 01142).

\section{DISCUSSION}

Denitrification removes nitrogen from a system by reducing nitrite or nitrate to $\mathrm{N}_{2}$ gas. Three sources of nitrite and nitrate for sediment denitrification are: (1) $\mathrm{NO}_{3}^{-}+\mathrm{NO}_{2}^{-}$diffusing into the sediments from the water column, (2) nitrification occurring in the sediments, and (3) $\mathrm{NO}_{3}^{-}+\mathrm{NO}_{2}^{-}$advected through the sediments from groundwater inputs. No direct measurements of the latter are available in Ochlockonee Bay. However, it is not likely that groundwater is a major source of $\mathrm{NO}_{3}^{-}+\mathrm{NO}_{2}^{-}$for denitrification in Ochlockonee Bay sediments since $\mathrm{NO}_{3}^{-}+\mathrm{NO}_{2}^{-}$concentrations in the local groundwater are low and the sediments were isolated during the denitrification measurements from any new groundwater inputs.

The major source of nitrite and nitrate for denitrification in Ochlockonee Bay sediments appears to be nitrification in the sediments, not diffusion of nitrite or nitrate from the water column. This conclusion is based on the finding that there was no measurable flux of nitrite or nitrate from the overlying water into the sediments in which denitrification was occurring (Table 1).

Nitrification in the sediments appears to be the major source of $\mathrm{NO}_{3}^{-}+\mathrm{NO}_{2}^{-}$for denitrification in most coastal marine sediments with oxic bottom waters (Seitzinger in press). This conclusion is based on the observation that there is generally a net flux of $\mathrm{NO}_{3}^{-}+\mathrm{NO}_{2}^{-}$out of sediments in which denitrification is occurring, or the rate of uptake of $\mathrm{NO}_{3}^{-}+\mathrm{NO}_{2}^{-}$from the water column is much less than that required to supply the reported denitrification rates (Table 3). Tama Estuary, Japan, sediments are an exception to this; there nitrate from the overlying water is the major source of nitrate for denitrification (Nishio et al. 1983). Nitrification in the sediments also appears to be the major source of nitrate for denitrification in a number of lakes and rivers (Seitzinger in press).

A large percentage of the $\mathrm{NO}_{3}^{-}+\mathrm{NO}_{2}^{-}$produced in Ochlockonee Bay sediments is denitrified, as indicated by a comparison of the denitrification rates and the flux of $\mathrm{NO}_{3}^{-}+\mathrm{NO}_{2}^{-}$out of the sediments (Table 1). An average (for all cores) of $80 \%$ of the $\mathrm{NO}_{3}^{-}+\mathrm{NO}_{2}^{-}$ produced in the sediments is denitrified. (The production of $\mathrm{NO}_{3}^{-}+\mathrm{NO}_{2}^{-}$was calculated as the sum of the measured $\mathrm{NO}_{3}^{-}+\mathrm{NO}_{2}^{-}$flux out of the sediment plus the $\mathrm{NO}_{3}^{-}$or $\mathrm{NO}_{2}^{-}$required to supply the measured denitrification [Table 4].) This assumes no reduction of $\mathrm{NO}_{3}$ or $\mathrm{NO}_{2}$ to $\mathrm{NH}_{4}$ (Koike \& Hattori 1978, Sorensen 1978 , Jenkins \& Kemp 1984) and thus may be a maximum estimate. This efficiency of removal implies a tight coupling between nitrification and denitrification, which may be due to denitrification occurring in reduced microenvironments within the aerobic surface 
Table 3. Sediment-water fluxes of ammonium, nitrate plus nitrite, and $\mathrm{N}_{2}$, and percent of $\mathrm{N}$ flux due to denitrification $\left(\mathrm{N}_{2}\right.$ flux $/\left[\mathrm{NH}_{4}+\mathrm{NO}_{3}+\mathrm{NO}_{2}+\mathrm{N}_{2}\right]$ flux $)$ in coastal marine sediments. units: $\mu \mathrm{g}$-at $\mathrm{N} \mathrm{m}^{-2} \mathrm{~h}^{-1}$

\begin{tabular}{|c|c|c|c|c|c|}
\hline Location & $\begin{array}{r}\mathrm{Fl} \\
\mathrm{NH}_{4}\end{array}$ & $\begin{array}{l}\mu g \text {-at } \mathrm{N} \mathrm{m}^{-} \\
\mathrm{NO}_{3}+\mathrm{NO}_{2}\end{array}$ & $\left.{ }^{1}\right) \mathrm{N}_{2}$ & $\begin{array}{l}\text { Percent } \\
\mathrm{N}_{2}\end{array}$ & Reference \\
\hline Narragansett Bay, USA & 91 & 10 & 59 & 37 & Seitzinger et al. 1984 \\
\hline $\begin{array}{l}\text { North Sea, Belgian Coa } \\
\text { Coastal } \\
\text { Offshore }\end{array}$ & $\begin{array}{l}73 \\
41\end{array}$ & $\begin{array}{l}98 \\
49\end{array}$ & $\begin{array}{l}49 \\
16\end{array}$ & $\begin{array}{l}22 \\
15\end{array}$ & $\begin{array}{l}\text { Billen } 1978 \\
\text { Billen } 1978\end{array}$ \\
\hline $\begin{array}{l}\text { North Sea } \\
\quad \text { Belgian Coast }\end{array}$ & 92 & 100 & 88 & 31 & Vanderborght et al. 1977 \\
\hline Patuxent Estuary, USA & 467 & -42 & 133 & 20 & Reported in Henriksen \& Kemp in press \\
\hline $\begin{array}{l}\text { Tejo Estuary, Portugal } \\
\text { Upper bay }\end{array}$ & 28 & 212 & 172 & 42 & Seitzinger unpubl. data \\
\hline $\begin{array}{l}\text { S. Island West Coast, N } \\
\text { Stn R200 } \\
\text { Stn R212 } \\
\text { Stn } 213\end{array}$ & $\begin{array}{l}17 \\
17 \\
21\end{array}$ & $\begin{array}{r}17 \\
8 \\
25\end{array}$ & $\begin{array}{l}10 \\
77 \\
53\end{array}$ & $\begin{array}{l}23 \\
75 \\
54\end{array}$ & $\begin{array}{l}\text { Kaspar et al. } 1985 \\
\text { Kaspar et al. } 1985 \\
\text { Kaspar et al. } 1985\end{array}$ \\
\hline $\begin{array}{l}\text { Lake Grevelingen, Neth } \\
\text { Saltwater } 1977\end{array}$ & & $139^{\circ}$ & 29 & 21 & de Vries \& Hopstaken 1984 \\
\hline Ochlockonee Bay & 15 & 18 & 73 & 69 & This study \\
\hline $\begin{array}{l}\text { Tama Estuary, Japan } \\
\text { December } \\
\text { May }\end{array}$ & & $\begin{array}{l}-28 \cdots \\
-119^{\cdots}\end{array}$ & $\begin{array}{l}15 \\
59\end{array}$ & & $\begin{array}{l}\text { Nishio et al. } 1983 \\
\text { Nishio et al. } 1983\end{array}$ \\
\hline
\end{tabular}

Table 4. Calculated sediment nitrification rates, percent of $\mathrm{N}$ efflux that is $\mathrm{N}_{2}$, and percent of benthic oxygen consumption used for nitrification in Ochlockonee Bay sediments. Rates used for calculations are from Table 1

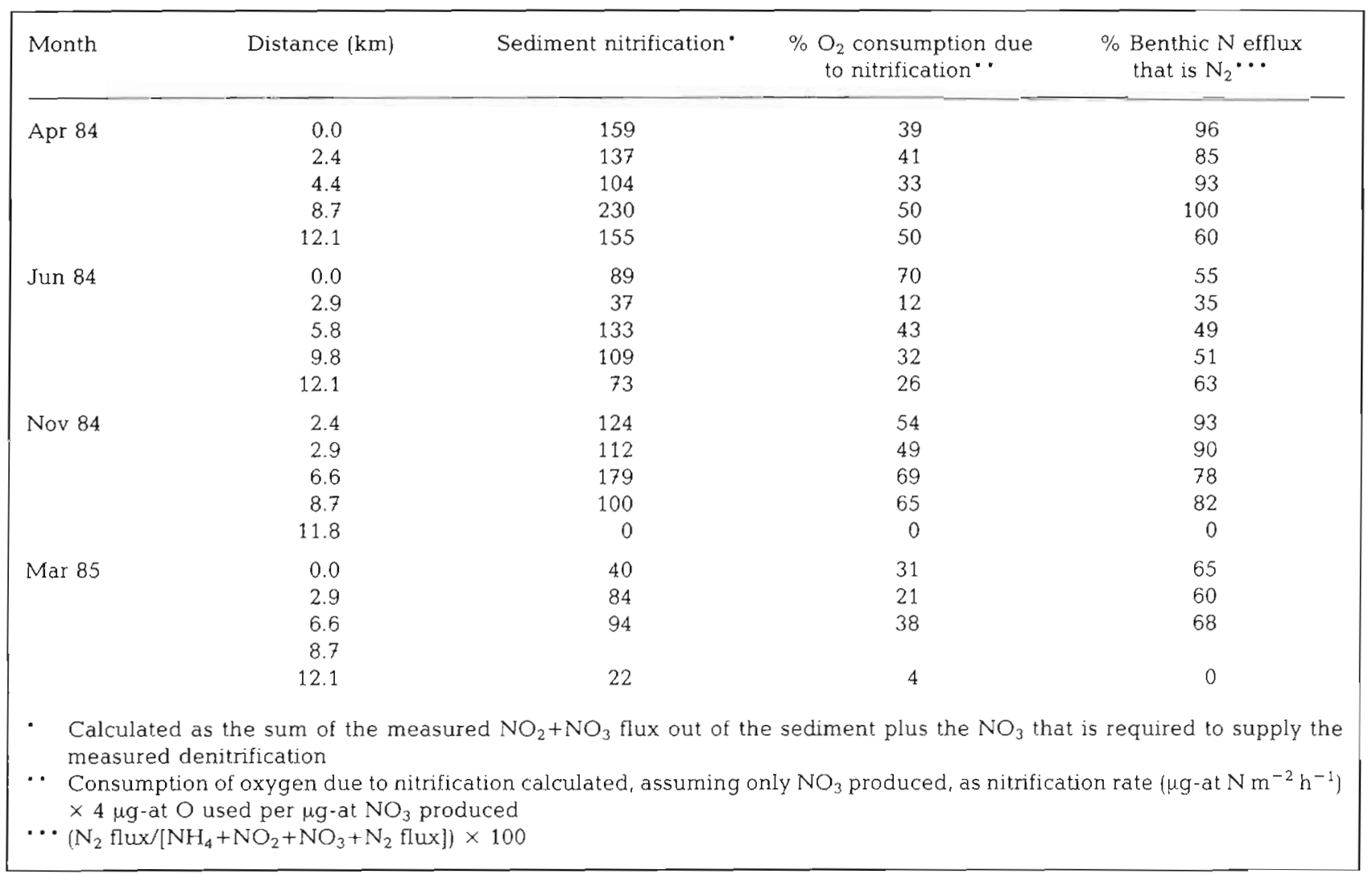


sediments or within aerobic sediments lining the burrows of certain infauna (Henriksen et al. 1983). The high percentage of nitrate and nitrite produced in the sediments that is denitrified suggests that the nitrification rate is an important factor controlling the denitrification rate. Jenkins \& Kemp (1984) observed a tight coupling between sediment nitrification and denitrification in Patuxent River (Chesapeake Bay, USA) estuary sediments where over $99 \%$ of ${ }^{15} \mathrm{~N}-\mathrm{NO}_{3}^{-}$produced in the sediments from added ${ }^{15} \mathrm{~N}_{-} \mathrm{NH}_{4}^{+}$was reduced to ${ }^{15} \mathrm{~N}-\mathrm{N}_{2}$. High efficiencies of nitrite and nitrate reduction by denitrification have also been reported in Narragansett Bay (Seitzinger et al. 1984) and from a MERL mesocosm nutrient-enrichment experiment (Seitzinger \& Nixon 1985). Denitrification reduced 62 to $100 \%$ of the nitrite and nitrate produced in those sediments; no pattern relative to temperature or degree of eutrophication was evident. Christensen \& Rowe (1984) calculated that sediment-related nitrification supplied all the nitrate for denitrification in Gulf of Maine sediments, and that $26 \%$ of the nitrate produced in the sediments was denitrified.

A major portion of the nitrogen cycled through the sediments in Ochlockonee Bay was not returned to the water column as ammonium, nitrite or nitrate for further use by the algae, but rather was lost from the system as $\mathrm{N}_{2}$. As an annual average, $69 \%$ of the benthic $\mathrm{N}$ flux $\left(\mathrm{NH}_{4}^{+}+\mathrm{NO}_{2}^{-}+\mathrm{NO}_{3}^{-}+\mathrm{N}_{2}\right)$ was $\mathrm{N}_{2}$. (This was calculated from the average annual $\mathrm{N}$ fluxes estimated by plotting the average $\mathrm{NH}_{4}^{+}, \mathrm{NO}_{2}^{-}+\mathrm{NO}_{3}^{-}$, or $\mathrm{N}_{2}$ flux in the bay as a function of the month of sediment collection and integrating the area under the curve.) This is similar to the percentage of benthic $\mathrm{N}$ fluxes that is $\mathrm{N}_{2}$ reported for other coastal marine sediments (Table 3). During summer in Ochlockonee Bay the amount of $\mathrm{N}$ lost from the benthic recycling pathway via denitrification is equivalent to approximately $40 \%$ of the $\mathrm{N}$ requirements of the phytoplankton. This calculation is based on a summer primary production rate of $15 \mathrm{mg} \mathrm{C} \mathrm{m}{ }^{-2} \mathrm{~h}^{-1}$ averaged over $24 \mathrm{~h}\left(30 \mathrm{mg} \mathrm{C} \mathrm{m}^{-2} \mathrm{~h}^{-1}\right.$ for a 12 h day; Meyers \& Iverson 1981, Kaul \& Froelich 1984), a C:N ratio of the phytoplankton of 6.625 by atoms, and an average denitrification rate in June for the 5 locations of $73 \mu \mathrm{g}$-at $\mathrm{N} \mathrm{m}^{-2} \mathrm{~h}^{-1}$.

Benthic $\mathrm{NH}_{4}^{+}$fluxes are quantitatively greater than benthic $\mathrm{NO}_{3}^{-}+\mathrm{NO}_{2}^{-}$fluxes in many coastal sediments (Nixon et al. 1976, Fisher et al. 1982, Boynton \& Kemp 1985). As such, the magnitude and importance of nitrification in the sediments has been somewhat obscured. The slow rates of nitrification reported in coastal waters (Hattori et al. 1978, McCarthy et al. 1984) and rapid pelagic ammonification rates (Harrison 1978 , Caperon et al. 1979, Glibert 1982) have also, I think, influenced our ideas about the relative rates of these 2 processes in sediments. However, as discussed above, a large percent of the nitrogen cycled through coastal sediments is denitrified and the $\mathrm{NO}_{3}^{-}+\mathrm{NO}_{2}^{-}$to support that denitrification comes from nitrification in the sediments. A comparison of the magnitude of $\mathrm{NO}_{3}^{-}+\mathrm{NO}_{2}^{-}$ $+\mathrm{N}_{2}$ fluxes with $\mathrm{NH}_{4}^{+}$fluxes indicates that in Ochlockonee Bay and in other coastal sediments over half of the organic nitrogen cycled through the sediments is oxidized in the sediments to $\mathrm{NO}_{3}^{-}$or $\mathrm{NO}_{2}^{-}$(Table 3). In Ochlockonee Bay approximately $80 \%$ of the nitrogen cycled through the sediments is nitrified. This calculation does not include the possible reduction of $\mathrm{NO}_{3}^{-}$or $\mathrm{NO}_{2}^{-}$to ammonium in the sediments (Koike \& Hattori 1978, Sorensen 1978, Jenkins \& Kemp 1984) and as such may be a minimum estimate.

It is interesting to compare rates of nitrification measured in coastal sediments with pelagic nitrification rates. In a review of nitrification in the marine environment, Kaplan (1983) reported that nitrification rates measured in coastal waters range from 0.0006 to

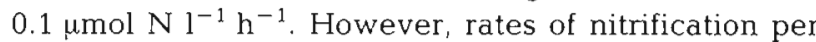
unit volume in coastal sediments are generally several orders of magnitude greater and range from 0 to 0.05 umol $\mathrm{N} \mathrm{cm}^{-3} \mathrm{~h}^{-1}$ with rates commonly $0.02 \mu \mathrm{mol} \mathrm{N} \mathrm{cm}{ }^{-3} \mathrm{~h}^{-1}$ (Kaplan 1983). Assuming a sediment porosity of $50 \%$, sediment nitrification rates range from 0 to $100 \mu \mathrm{mol} \mathrm{N}^{-1} \mathrm{~h}^{-1}$, with $40 \mu \mathrm{mol} \mathrm{N}$ $\mathrm{l}^{-1} \mathrm{~h}^{-1}$ common. The high rates of nitrification in sediments relative to the water column may reflect the high $\mathrm{NH}_{4}^{+}$concentrations typical of coastal sediments. Of course a comparison of the total amount of $\mathrm{NO}_{3}^{-}+\mathrm{NO}_{2}^{-}$ produced in the water and sediments must take into consideration the total volume of the water column and the sediments in which nitrification occurs.

Nitrification alone in the sediments accounts for an average of $38 \%$ of the sediment oxygen consumption (Table 4 ; average of all cores). (The oxygen consumption due to nitrification was calculated by multiplying the calculated nitrification rate $\left[\mathrm{NO}_{3}^{-}+\mathrm{NO}_{2}^{-}\right.$flux $+\mathrm{N}_{2}$ production] for a core by 4 , because $4 \mu \mathrm{g}$-at $\mathrm{O}_{2}-\mathrm{O}$ are consumed per $\mu \mathrm{g}$-at of $\mathrm{NO}_{3}^{-}$produced.) Other studies have shown that nitrification accounts for a similarly high percentage of benthic oxygen consumption. In Narragansett Bay (Rhode Island, USA) approximately 30 to $50 \%$ of the sediment oxygen consumption at the mid to lower bay sites was attributed to nitrification (Seitzinger et al. 1984) and 30 to $50 \%$ across a eutrophication gradient in the MERL mesocosms (Seitzinger \& Nixon 1985). Christensen \& Rowe (1984) estimated that $35 \%$ of the oxygen consumption in Gulf of Maine sediments is related to nitrification. In Danish coastal sediments and Chesapeake Bay sediments, nitrification accounts for a smaller percent of the sediment oxygen consumption, averaging 7 and $8 \%$, respectively (Henriksen \& Kemp in press).

Denitrification rates were significantly $(\alpha=0.01)$ cor- 
related with sediment oxygen consumption: $\mathrm{N}_{2}$ ( $\mu$ g-at $\left.\mathrm{N} \mathrm{m}^{-2} \mathrm{~h}^{-1}\right)=0.083 \mathrm{O}_{2}\left(\mu \mathrm{g}\right.$-at $\left.\mathrm{Om}^{-2} \mathrm{~h}^{-1}\right)+2$, with $\mathrm{r}=$ 0.65 (excluding the March data from the sediments collected outside the mouth of the bay). While free oxygen is not directly used during denitrification, the correlation between oxygen consumption and denitrification rates likely reflects the close relationship between denitrification and nitrification rates. A large percentage of the benthic oxygen consumption is due to nitrification as discussed above. In addition, oxygen is used indirectly for nitrification since oxygen is consumed during the decomposition of organic matter which produces ammonium that is oxidized during nitrification.

The direct measurements of denitrification in Ochlockonee Bay during 1984-85 are considerably greater than the annual average denitrification rate estimated by Kaul \& Froelich (1984) of $7.2 \mu \mathrm{g}$-at $\mathrm{N} \mathrm{m}^{-2} \mathrm{~h}^{-1}$ based on a model of nitrate and salinity distributions in the water column in the bay during 1980-81. There are a number of possible reasons for the difference. It is not clear exactly what the difference would have been in the predicted denitrification rates if Kaul \& Froelich's (1984) model had included ammonium or total nitrogen inputs and distributions. Also, river inputs of dissolved inorganic nitrogen during Kaul \& Froelich's (1984) study were about 3 times lower than during a normal flow year, as discussed above. However, the rate of the internal input of nitrogen from benthic fluxes during 1980-81 was likely influenced by the mineralization of organic matter deposited during previous years when river inputs of nitrogen to the bay were greater. As such, there may have been a net internal benthic source of nitrogen to the bay during 1980-81 which would have masked the actual rate of denitrification. Direct measurements of denitrification and benthic $\mathrm{NH}_{4}^{+}$and $\mathrm{NO}_{3}^{-}+\mathrm{NO}_{2}^{-}$fluxes during a number of years when nitrogen input rates to the bay differ are needed to resolve this.

The riverine input of dissolved inorganic nitrogen
(DIN) to Ochlockonee Bay (135 $\mu \mathrm{g}$-at $\left.\mathrm{N} \mathrm{m}^{-2} \mathrm{~h}^{-1}\right)$ during years of normal river flow (in contrast to drought years when the input is $\sim 45 \mu \mathrm{g}$-at $\mathrm{N} \mathrm{m}^{-2} \mathrm{~h}^{-1}$ ) is similar to the DIN input to a number of other estuaries that receive substantial anthropogenic nitrogen inputs, such as Narragansett Bay (108 $\mu$ g-at $\mathrm{N} \mathrm{m}^{-2} \mathrm{~h}^{-1}$ ) and Delaware Bay (148 $\mu \mathrm{g}$-at $\mathrm{N} \mathrm{m}^{-2} \mathrm{~h}^{-1}$ ), and is about twice as great as the DIN inputs to Chesapeake Bay $(58 \mu$ g-at $N$ $\mathrm{m}^{-2} \mathrm{~h}^{-1}$ ) (DIN inputs as reported by Nixon \& Pilson [1983]). The relatively high rate of nitrogen input to Ochlockonee Bay, in the absence of major anthropogenic nutrient inputs, is likely due to the large watershed area relative to the area of the bay compared to the above estuaries (Table 5). The ratio of watershed area to estuarine area is approximately 10 times greater for Ochlockonee Bay than many other estuaries, and results in a high freshwater input rate relative to the size of the estuary. The large freshwater input rate also leads to a short residence time for water in Ochlockonee Bay with the average during the study period being ca 3 d based on Kaul \& Froelich's (1984) model of river flow vs residence time of water in Ochlockonee Bay. This contrasts with residence times on the order of weeks to months reported for many other estuaries.

Denitrification is a major sink for terrestrially derived nitrogen inputs to Ochlockonee Bay. The annual denitrification rate in Ochlockonee Bay was calculated by plotting the average denitrification rate in the bay as a function of month of collection and integrating the area under the curve. The magnitude of this sink for nitrogen was $73 \mu \mathrm{g}$-at $\mathrm{N} \mathrm{m}^{-2} \mathrm{~h}^{-1}$. A comparison of the annual riverine input of DIN during the study period (1 Apr 1984 to $31 \mathrm{Mar} 1985$ ) (135 $\mu$ g-at $\mathrm{N} \mathrm{m}^{-2} \mathrm{~h}^{-1}$ ) with the annual denitrification rate measured during the same time interval ( $73 \mu \mathrm{g}$-at $\mathrm{N} \mathrm{m}^{-2} \mathrm{~h}^{-1}$ ) demonstrates that denitrification removed from the bay an amount of $\mathrm{N}$ equivalent to approximately $54 \%$ of the riverine input of DIN (Table 6). This fairly high efficiency of removal of $\mathrm{N}$ via denitrification in an estuary with such

Table 5. Freshwater input rate, drainage basin area and estuarine surface area for a number of USA estuaries

\begin{tabular}{|lccccl}
\hline Estuary & $\begin{array}{c}\text { Freshwater } \\
\text { input }\left(\mathrm{m}^{3} \mathrm{~s}^{-1}\right)\end{array}$ & $\begin{array}{c}\text { Drainage basin } \\
\left(10^{3} \mathrm{~km}^{2}\right)\end{array}$ & $\begin{array}{c}\text { Estuary } \\
\left(\mathrm{km}^{2}\right)\end{array}$ & $\begin{array}{c}\text { Area ratio } \\
\text { Drainage: Estuary }\end{array}$ & Reference \\
\hline Ochlockonee Bay & 62.4 & 5.8 & 24 & 242 & US Geological Survey unpubl. data \\
Narragansett Bay, RI & 105 & 4.7 & 328 & 14 & Pilson 1985 \\
Delaware Bay & 447 & 33 & 1942 & 17 & Sharp et al. 1982 \\
Chesapeake Bay & 2265 & 166 & 11300 & 15 & Burger 1982, Wells et al. 1983 \\
Neuse River Estuary, NC & 5.5 & 11 & 400 & 28 & Fisher et al. 1982 \\
South River Estuary, NC & 1 & 0.2 & 25 & 8 & Fisher et al. 1982 \\
Barataria Bay, LA & \multicolumn{7}{c}{ Day et al. 1982 } \\
- Area of estuary from planimetry of US Geological Survey maps No. 00624 and 01142 &
\end{tabular}


Table 6. Known sources and sinks of nitrogen in Ochlockonee Bay, Florida, April 1984 to April 1985

\begin{tabular}{|c|c|c|}
\hline \multicolumn{3}{|c|}{$\begin{array}{c}\text { Flux } \\
\left(\mu g \text {-at } \mathrm{N} \mathrm{m}^{-2} \mathrm{~h}^{-1}\right)\end{array}$} \\
\hline \multicolumn{3}{|l|}{ Sources" } \\
\hline Rivers (DIN) & 135 & This study \\
\hline Precipitation & 6 & Hendry \& Brezonik 1980 \\
\hline $\mathrm{N}_{2}$-fixation & $\leq 0.4$ & Seitzinger unpubl data \\
\hline Total & 141 & \\
\hline \multicolumn{3}{|l|}{ Sinks } \\
\hline Burial & $?$ & \\
\hline Export & ? & \\
\hline Denitrification & 73 & This study \\
\hline Total & +73 & \\
\hline \multicolumn{3}{|c|}{$\begin{array}{l}\text { Adequate data are not available to estimate offshore } \\
\text { inputs. However, offshore inputs appear to be small } \\
\text { relative to river inputs based on the following: annual } \\
\text { average DIN in water at mouth of bay } \sim 1 \mu \mathrm{M} \text {, flushing } \\
\text { time of bay } \sim 3 \mathrm{~d} \text {, and volume of bay } \sim 2.4 \times 10^{7} \mathrm{~m}^{3} \\
\text { Offshore input then calculated as }\left(1 \mu \mathrm{g} \text {-at } \mathrm{N}^{-1} \times\right. \\
\left.2.4 \times 10^{10} 1 \times\left[0.0139 \text { times } \mathrm{h}^{-1}\right]\right) / 2.4 \times 10^{7} \mathrm{~m}^{2}=14 \mu \mathrm{g} \text {-at } \\
\mathrm{N} \mathrm{m}^{-2} \mathrm{~h}^{-1}\end{array}$} \\
\hline
\end{tabular}

a short water residence time $(\sim 3 \mathrm{~d})$ may be related, in part, to the shallow water column ( $\sim 1 \mathrm{~m}$ at low tide); such a shallow water column may increase the number of times $\mathrm{N}$ is cycled through the sediments and is subject to removal via denitrification, compared to deeper estuaries, before being transported offshore.

The importance of denitrification as a sink for nitrogen inputs to Ochlockonee Bay is similar to that in other estuaries for which data are available. In Narragansett Bay, denitrification removes an amount of nitrogen equivalent to $50 \%$ of the DIN river and sewage inputs on an annual basis (Seitzinger et al. 1984). In the Tejo Estuary, Portugal, denitrification rates measured throughout the estuary during October (average $232 \mu \mathrm{g}$-at $\mathrm{N} \mathrm{m}^{-2} \mathrm{~h}^{-1}$; Seitzinger unpubl. data) were equivalent to approximately $45 \%$ of the average DIN input from river-carried $\mathrm{N}$ and direct sewage sources to the estuary $\left(516 \mu \mathrm{g}\right.$-at $\mathrm{N} \mathrm{m}^{-2} \mathrm{~h}^{-1}$; Portuguese National Commission for the Environment unpubl. data). In Four League Bay (Louisiana, USA) denitrification removes an amount of $\mathrm{N}$ equivalent to $20 \%$ of the river inputs of $\mathrm{NO}_{3}^{-}$on an annual basis (Smith et al. 1985). In the Baltic Sea denitrification annually removes an amount of nitrogen equivalent to $40 \%$ of the nitrogen inputs (Larsson et al. 1985). If the results from the above estuaries hold for estuaries in general, this implies that denitrification not only decreases the amount of $\mathrm{N}$ recycled for primary production within estuaries, but also effectively decreases, by as much as 40 to $50 \%$, the amount of river-supplied $N$ (both natural and anthropogenic) transported to continental shelves and the open ocean.
Acknowledgements. Support for this work was provided through NSF Grant OCE8315756. Clare E. Casselberry carried out much of the field and laboratory work and assisted in the data interpretation. P. N. Froelich provided assistance with the initial field sampling, provided laboratory space at Florida State University for portions of the work, and provided many helpful suggestions and insights into Ochlockonee Bay. I also thank the personnel at the Florida State University's Marine Laboratory for their assistance with this work.

\section{LITERATURE CITED}

Billen, G. (1978). A budget of nitrogen recycling in North Sea sediments off the Belgian coast. Estuar. coast. mar. Sci. 7: $127-146$

Blackburn, T H., Henriksen, K. (1983). Nitrogen cycling in different types of sediments from Danish waters. Limnol. Oceanogr. 28 (3): $477-493$

Boynton, W R., Kemp, W. M. (1985). Nutrient regeneration and oxygen consumption by sediments along an estuarine salinity gradient. Mar. Ecol. Prog. Ser. 23: 45-55

Boynton, W. R., Kemp, W. M., Keefe, C. W. (1982). A comparative analysis of nutrients and other factors influencing estuarine phytoplankton production. In: Kennedy, V S. (ed.) Estuarine comparisons. Academic Press, New York, p. $69-90$

Burger, N. (1982). Areal, volumetric and average depth statistics for the Chesapeake Bay and its tributaries by CBP segment. Working memorandum, U.S. Environmental Protection Agency. Chesapeake Bay Program, Annapolis, Maryland

Caperon, J., Schell, D., Hirota, J., Laws, E. (1979). Ammonium excretion rates in Kaneohe Bay, Hawaii, measured by a ${ }^{15} \mathrm{~N}$ isotope dilution technique. Mar. Biol. 54: 33-40

Christensen, J. P., Rowe, G. T. (1984). Nitrification and oxygen consumption in northwest Atlantic deep-sea sediments. J. mar. Res. 42; 1099-1116

Day, J. W., Jr., Hopkinson, C. S., Conner, W H. (1982). An analysis of environmental factors regulating community metabolism and fisheries production in a Louisiana estuary. In: Kennedy, V. S. (ed.) Estuarine comparisons. Academic Press, New York, p. 121-136

de Vries, I., Hopstaken, C. F. (1984). Nutrient cycling and ecosystem behaviour in a salt-water lake. Neth. J. Sea Res. $18(3 / 4): 221-245$

Fisher, T. R., Carlson, P. R., Barber, R. T. (1982). Sediment nutrient regeneration in three North Carolina estuaries. Estuar. coast. Shelf Sci. 14: 101-116

Glibert, P. M. (1982). Regional studies of daily, seasonal and size fraction variability in ammonium remineralization. Mar. Biol. 70: 209-222

Harrison, W. G. (1978). Experimental measurements of nitrogen remineralization in coastal waters. Limnol. Oceanogr. 23: $684-694$

Harrison, W. G., Hobbie, J. E. (1974). Nitrogen budget of a North Carolina estuary, Water Res. Inst., Univ. North Carolina, Report No. 86, p. 172

Hattori, A., Goering, J. J., Boisseau, D. B. (1978). Ammonium oxidation and its significance in the summer cycling of nitrogen in oxygen deplete Skan Bay, Unalaska Island, Alaska. Mar. Sci. Commun. 4: 139-151

Hendry, C. D., Brezonik, P. L. (1980). Chemistry of precipitation at Gainsville, Florida. Environ. Sci. Tech. 14: 843-849

Henriksen, K., Kemp, W. M. (in press). Nitrification in estuarine and coastal marine sediments: methods, patterns 
and regulating factors. In: Sorensen, J., Blackburn, $\mathrm{T} H$. Rosswall, $T$ (ed.) Nitrogen cycling in coastal marine sediments. John Wiley \& Sons, New York

Henriksen, K., Rasmussen, M. B., Jensen, A. (1983). Effect of bioturbation on microbial nitrogen transformations in the sediment and fluxes of ammonium and nitrate to the overlying water. Ecol. Bull. (Stockholm) 35: 193-205

Jenkins, M. C., Kemp, W. M. (1984). The coupling of nitrification and denitrification in two estuarine sediments. Limnol. Oceanogr. 29 (3): 609-619

Kaplan, W. A. (1983). Nitrification. In: Carpenter, E. J., Capone, D. G. (ed.) Nitrogen in the marine environment. Academic Press, New York, p. 139-190

Kaspar, H. F., Asher, R. A., Boyer, I. C. (1985). Microbial nitrogen transformations in sediments and inorganic nitrogen fluxes across the sediment-water interface on the South Island West Coast, New Zealand. Estuar. coast. Shelf Sci. 21: 245-255

Kaul, L. W., Froelich, P. N., Jr (1984). Modeling estuarine nutrient geochemistry in a simple system. Geochim. Cosmochim. Acta 48: 1417-1433

Koike, I., Hattori, A. (1978). Denitrification and ammonia formation in anaerobic coastal sediments. Appl. environ. $\mathrm{Mi}$ crobiol. 35 (2): 278-282

Larsson, U., Elmgren, R., Wulff, F. (1985). Eutrophication and the Baltic Sea: causes and consequences. Ambio 14 (1): $10-14$

McCarthy, J. J., Kaplan, W. A., Nevins, J. L. (1984). Chesapeake Bay nutrient and plankton dynamics. 2. Sources and sinks of nitrite. Limnol. Oceanogr 29: 84--98

Meybeck, M. (1982). Carbon, nitrogen, and phosphorus transport by world rivers. Am. J. Sci. 282: 401-450

Myers, V. B., Iverson, R. I. (1981). Phosphorus and nitrogen linited phytoplankton productivity in northeastern Gulf of Mexico coastal estuaries. In: Neilson, B. J., Cronin, L. E. (ed.) Estuaries and nutrients. Humana, Clifton, New Jersey, p. 569-582

Nishio, T., Koike, I., Hattori, A. (1983). Estimates of denitrification and nitrification in coastal and estuarine sediments. Appl. environ. Microbiol. 45 (2): $444-450$

Nixon, S. W (1981). Remineralization and nutrient cycling in coastal marine ecosystems. In: Neilson, B. J., Cronin, L. E. (ed.) Estuaries and nutrients. Humana, Clifton, New Jersey, p. 111-138

Nixon, S. W., Oviatt, C. A., Hale, S. S. (1976). Nitrogen regeneration and the metabolism of coastal marine bottom communities. In: Anderson, J. M., Mcfadyen, A. (ed.) The role of terrestrial and aquatic organisms in decomposition processes. Blackwell Scientific, Oxford, p. 269-283

Nixon, S. W. Pilson, M. E. Q. (1983). Nitrogen in estuarine and coastal marine ecosystems. In: Carpenter, E. J., Capone, D.
G. (ed.) Nitrogen in the marine environment. Academic Press, New York, p. 565-648

Pilson, M. E. Q. (1985). On the residence time of water in Narragansett Bay. Estuaries 8 (1): 2-14

Rowe, G. T., Clifford, C. H., Smith, K. L., Jr (1975). Benthic nutrient regeneration and its coupling to primary productivity in coastal waters. Nature, Lond. 255: 215-217

Seitzinger, S. P. (1982). The importance of denitrification and nitrous oxide production in the nitrogen dynamics and ecology of Narragansett Bay, Rhode Island. Ph.D. thesis, Univ. Rhode Island

Seitzinger, S. P. (in press). Denitrification in freshwater and coastal marine ecosystems: ecological and geochemical significance. In: Nixon, S. W. (ed.) Comparative ecology of fresh water and coastal marine ecosystems. Limnol. Oceanogr., Special Publication No. 4

Seitzinger, S. P., Nixon, S. W., Pilson, M. E. Q. (1984). Denitrification and nitrous oxide production in a coastal marine ecosystem. Limnol. Oceanogr. 29 (1): 73-83

Seitzinger, S. P., Nixon, S. W. (1985). Eutrophication and the rate of denitrification and $\mathrm{N}_{2} \mathrm{O}$ production in coastal marine sediments. Limnol. Oceanogr. 30 (6): 1332-1339

Seitzinger, S., Nixon, S. W., Pilson, M. E. Q., Burke, S. (1980). Denitrification and $\mathrm{N}_{2} \mathrm{O}$ production in near-shore marine sediments. Geochim. Cosmochim. Acta 44: 1853-1860

Sharp, J. H., Culberson, C. H., Church, T M. (1982). The chemistry of the Delaware estuary. General considerations. Limnol. Oceanogr. 27 (6): 1015-1028

Smith, C. J., DeLaune, R. D., Patrick, W. H., Jr (1985). Fate of riverine nitrate entering an estuary: I. Denitrification and nitrogen burial. Estuaries 8 (1): 15-21

Solorzano, L. (1969). Determination of ammonia in natural waters by the phenylhypochlorite method. Limnol. Oceanogr. 14: 799-801

Sorensen, J. (1978). Capacity for denitrification and reduction of nitrate to ammonia in a coastal marine sediment. Appl environ. Microbiol. 35: 301-305

Technicon Industrial Systems (1977). Nitrate and nitrite in water and seawater. Industrial Method No. 158-71W/A. Technicon Industrial Systems, Tarrytown, New York, p. $1-4$

Vanderborght, J., Wollast, R., Billen, G. (1977). Kinetic models of diagenesis in undisturbed sediments Part 2. Nitrogen diagenesis. Limnol. Oceanogr. 22 (5): 794-803

Weiss, R. F., Price, B. A. (1980). Nitrous oxide solubility in water and seawater. Mar. Chem. 8: 347-359

Wells, H. W., Jr, Katsanos, S. J., Flanigan, F. H. (1983). An introduction to Chesapeake Bay. In: Chesapeake Bay: a framework for action. U.S. Environmental Protection Agency. Chesapeake Bay Program, Annapolis, Maryland, p. $3-14$ 